\title{
Psychological and Biological Perspective of Sickle Cell Anemia: A Systematic Review of Literature
}

\author{
Dr. Gaukaran, Janghel, $\mathrm{Ph} \mathrm{D}^{1 *}$, Dr. Rajesh Kumar, Ajagalley, $\mathrm{MD}^{2}$, \\ Dr. Vimal Chandra, Bhagat, $\mathrm{MD}^{3}$
}

\section{ABSTRACT}

Sickle cell anaemia is an autosomal recessive, monogenic hereditary haemolytic disorder. It is a structural variant of haemoglobin in which a glutamic acid at position 6 of $\beta$-polypeptide chain of haemoglobin is replaced by another amino acid, valine. The present study to find out the biological and psychological factors were associated with the risk factors for the origin of sickle cell anemia. The study conducted in different electronic databases, there were 65 studies related to sickle cell anemia and 22 studies were dealing with etiology, origin of sickle cell anemia. Finding of the literature suggested that biological, and psychological factors were associated with the origin of sickle cell anemia.

Keywords: Sickle Cell Anemia, Biological and Psychological Factors

Sickle cell anemia is an autosomal recessive, monogenic hereditary hemolytic disorder. It is a structural variant of hemoglobin in which a glutamic acid at position 6 of $\beta$-polypeptide chain of hemoglobin is replaced by another amino acid, valine (Pauling et. al, 1949). Hemoglobin molecule becomes mutant which is the cause of crescent/sickle shaped red cells, therefore, it is known as sickle cell. This happens due to change of nucleotide Adenine to Thymine of codon 6 of beta-globin gene located on the short arm of chromosome no. 11(Steinberg et. al, 2001). Normally the human RBCs are disc shaped. They move easily through blood vessels and carry the oxygen from the lungs to the rest of the body. The abnormal crescent shaped hemoglobin cannot move easily through the blood vessels and become stiff, sticky and tend to form clumps and get stuck in the blood vessels, that cause acute pain, serious infection and organ damage

\footnotetext{
${ }^{1}$ (Psychology) Clinical psychologist, Late Lakhiram Agrawal Memorial Govt. Medical College, Raigarh, C.G., India

2 (Psychiatry) Assistant Professor \& HOD, Late Lakhiram Agrawal Memorial Govt. Medical College, Raigarh, C.G., India

${ }^{3}$ (Psychiatry) Assistant Professor, Late Lakhiram Agrawal Memorial Govt. Medical College, Raigarh, C.G., India *Responding Author
}

Received: December 30, 2016; Revision Received: January 20, 2017; Accepted: January 30, 2017

(C) 2017 Janghel G, Ajagalley R, Bhagat V; licensee IJIP. This is an Open Access Research distributed under the terms of the Creative Commons Attribution License (www.creativecommons.org/licenses/by/2.0), which permits unrestricted use, distribution, and reproduction in any Medium, provided the original work is properly cited. 


\section{Psychological and Biological Perspective of Sickle Cell Anemia: A Systematic Review of Literature}

(such as spleen, liver, kidneys and lungs). Sickle cells usually die in only about 10 - 20 days while life span of normal red blood cells is up to 120 days. There is no cure for sickle celldisease however, hydroxyurea, blood transfusion, bonemarrow or stem-cell transplantation are some of the remedial measures to prevent asevere form of crisis.

Sickle cell disease was first reported by Prof. J.M. Herrick (1910) in Africa which was later named sickle cell anemia by Mason in 1922. When one gene is inherited from one parent, the person is said to be acarrier (HbAS) and when from both the parents the individual victims sickle cell disease. The homozygous (HbSS) is more severe than heterozygous (HbAS). Person with sickle cell trait (Heterozygous, HbAS) leads a normal life but the Sickle cell disease (Homozygous, HbSS) person suffer from various complications throughout the life such as anemia, jaundice, foot and hand syndrome, recurrent infection, osteomyelitis, necrosis of bone, aplastic crisis, abdominal pain, spleen sequestration crisis, hepatosplenomegaly (Serjeant \& Serjeant,2001). It is an important public health challenge in India. They cause a high degree of morbidity, mortality, and fetal wastage in vulnerable communities (Balgir, 2007). Sickle cell is common genetic disorder especially among the Scheduled Caste (SC) and Scheduled Tribe (ST) in central India (Bhatia and Rao, 1986; Pandey et. al, 1992).

Sickle cell genes are very frequent in economically and socially backward communities known as schedule caste (SC), schedule tribe (ST) and other backward classes (OBC). As per WHO (2006) report there are about 7 percent carriers of sickle cell disease, Thailandtopsthe world, out of which 2.70 crore carriers from India. Sickle cell gene was first detected in India by Lehman and Cutbush (1952) among the Irula and tribal groups of Nilgiri Hills (Dunlop and Mazumdar, 1952).

In Chhattisgarh around 15-18 percent of thepopulation is affected by the sickle cell disease and more than 50 percent of the affected children in the state die before the age of 5 yrs. (IANS, Apr. 2011). The high frequency of sickle cell gene occurs among the Scheduled Caste and Scheduled Tribe and other backward classes (Patra, et. al. 2011). According to Red Cross society, 30 lakh people are carriers (HbAS) and 2.5 lakh are sufferers of sickle cell disease.

Dampier, et. al. 2002 and Platt,et. al, 1991 reported that the occurrence of vaso-occlusive pain is higher in adolescents than children. Earlier studies showingthat children with sickle cell disease exhibit fewer behavioral problems \& less maladjustment than adolescents with sickle cell disease (Hurtig \& White, 1986)

\section{Rationale of the study}

The rationale for the current review study /historical study, the prevalence of sickle cell disease is very high in India, especially in Chhattisgarh state found that prevalence of sickle cell disease is high. The persons affected belongs to different socio-economic status and region.

(c) The International Journal of Indian Psychology, ISSN 2348-5396 (e)| ISSN: 2349-3429 (p) | 107 


\section{METHOD}

Sickle cell anemia disease related studies were searched for different electronic sources from 1950 to 2014, total 64 studies were found related to sickle cell anemia disease and 22 studies were mostly relevant to the present objective.

\section{Objective}

The objective of the study to find out that psychological variables are associated inorigins of sickle cell anemiain adolescent's population.

\section{SYSTEMATIC REVIEW OF LITERATURE}

\section{Biological Factors-}

Pauling, et al. (1949) obtained abnormal haemoglobin by electrophoresis in which protein with the same molecular weight but different charges migrate at different rates. He separated normal haemoglobin and sicklehaemoglobin with electrophoresis and showed that it is recessive, not Mendelian dominant. Lehman and Cutbush (1952) reported the presence of the trait in considerable frequencies in some of the tribal populations in and around Nilgiri Hills in South India. Severe joint pains and amilder type of jaundice are peculiar symptoms amongst sicklers. The affected individuals thus suffer from a variety of problems including heart failure, pneumonia, paralysis, kidney failure, abdominal pain, and rheumatism.

Ingram ( 2004) obtained the molecular charge in the haemoglobin molecule of sickle cell anaemia. He investigated the amino acid sequences of the alpha- and beta- polypeptide chains of the two types of haemoglobin, $\mathrm{HbA}$, and $\mathrm{HbS}$ and found that the alpha- chain is normal in both the amino acid sequences. In beta chains, there is a defect in a single amino acid that is the change of glutamic acid with the Valine at the sixth position. This lead to sickling of the red cells in the individuals with sickle cell anaemia.

Jain (1989) has reported after a screening of tribal populations from Bihar, Madhya Pradesh, Gujarat and Rajasthan and out of the total number screened, 110 were normal 44 had sickle cell trait and 6 homozygous sickle cell gene. Kate and Lingojwar (2002) studied to find out the prevalence of sickle cell disorder. They screened major communities from Maharashtra state and found high prevalence amongst schedule caste, schedule tribe, and other backward classes. Severe joints pain and amilder type of jaundice are peculiar symptoms amongst sickling patients from the state of Maharashtra. Balgir (2005) studied hemoglobinopathies of 1,015 cases. He observed 29.8 percent sickle cell trait (HbAS) and 7.5 percent sickle cell disease (HbSS). Sickle cell disorders with ahigh level of fetal hemoglobin were common in general castes (0.320.7percent), scheduled castes (0-8.9percent) and scheduled tribes (0-5.5percent).

Gupta (2006) studied the prevalence of sickle cell gene in Madhya Pradesh. He found that sickle cell disorder exists among scheduled tribes, scheduled castes, and backward class communities. 


\section{Psychological and Biological Perspective of Sickle Cell Anemia: A Systematic Review of Literature}

The study also revealed that sickle cell disease is very alarming in Madhya Pradesh. About 3358 newborn babies with sickle cell disease are expected every year and about 13,432 pregnancies are at risk annually. Singh et al. (2008) analyzed total 195 blood samples for sickle haemoglobin in Gond tribe of Panna district of Madhya Pradesh. 6.7 percent of the population was found to be sickle cell trait and 0.5 percent was deficient for G6PD enzyme. The overall prevalence of anaemia (as per WHO standard) was 77.4 percent, frequency of sickle cell gene was 0.0333 and population were in equilibrium state for sickle cell gene as per Hardy-Weinberg's Law (p>0.05).

Balgir (2010) studied genetic diversity of haemoglobinopathies in Kharia tribe of Sundergarh district of Orissa. He performed screening of 767 samples out of which frequency of sickle cell disorder was 5.6 percent whereas Dhelki Kharia had ahigh prevalence of sickle cell allele 12.4 percent. Doshi (2011) studied theprevalence of sickle cell disease in rural Pipalwada, Gujarat. Total 395 subjects were studied from 2003-2005 in which the incidence of sickle cell trait was found to be 7.86 percent among different communities.Patra, et al (2011) designed a screening program of sickle cell disease in which he screened 359823 subjects and covered 2087 (99.7 percent) villages of Raipur, Chattisgarh, between Oct. 2007 to June 2010 and the focus group were children aged 3-15 years. The sickle cell trait occurred in 9.30 percent and disease in 0.21 percent. Patra reported that high frequency of the sickle cell gene occurred among the scheduled tribe (Halba 16 percent, Gond 13 percent, Binjhwar 11 percent), Schedule castes Ghasia 24 percent, Ganda 22 percent and Mahar 12 percent ) and the other backward classes (Agharia 19 percent, Kosta 17 percent, Kurmi 16 percent, Teli 15 percent, and Kumhar 10 percent ). Patra also found asignificant relation of age with sickle cell trait prevalence.

\section{Psychological Factors:}

Whitten, et al (1974) conducted the study about psychosocial effects of sickle cell disease. He reported that psychosocial adaptation of an individual with sickle cell anemia is dependent on a number of variables, including the personality structure, family attitudes and behavior, and community responses and resources. Interactions of the individual, family, and community, and areas of stress and crises are analyzed bymeans of a developmental-maturational approach. Accurate knowledge of the disease, anticipatory guidance and continued (intermittent) counseling by trained health professionals, encourage and facilitate positive adaptations. He found negative psychosocial impact on individuals with sickle cell trait and anemia. Ohaeri, et al (1995) examined 170 sickle cell disease patients with the aim to know the coping strategies of sickle cell disease and associated psychosocial factors. He found the patients had common complaints viz. limitations illness placed on social life, depression about the illness, abnormal habitus, irritability, and suicidal ideation during crisis, burden of illness on the family, loneliness and feeling of inferiority. The most commonly coping style was prayer and followed by attempts of encouraging self. The other coping style were medically oriented approaches, attempts to avoid the problematic situations. Harris, etal. ( 1998),studied psychological impact and experience of hospital service of adult sickle cell patients, and observed that 63 percent patients 


\section{Psychological and Biological Perspective of Sickle Cell Anemia: A Systematic Review of Literature}

had received a diagnosis for sickle cell disease between birth and 5 years of age, 42 percent patients had experienced a painful crisis on average once a month or more frequently. The study provided evidence of the psychological and social impact of disease from the patients perspective, 62.5 percent were in the clinical range of psychological distress and depression.

Hasan, et al. ( 2003) assessed the prevalence of depressive symptoms, contribution of demographics, disease severity, and health care use variable to depressive symptoms in 27 men and 23 women sickle cell patients through the Beck Depressive inventory (BDI). The patient more likely to be depressed were: those with low family income $(<\$ 10,000)$, low school education, female, those who had multiple blood transfusions, poor pain control, inadequate social support, hydroxyurea use and had history of frequent vaso-occlusive crises.Anie (2005) examined psychological complications in sickle cell disease with a focus in three key areas: psychological complications were identified in both children and adult with sickle cell disease, and included inappropriate pain coping strategies; reduced quality of life owing to restrictions in daily functioning, anxiety and depression; and neuro-cognitive impairment. According to Anie (2005) utilization of psychological interventions including patient education, cognitive behavioral therapy and special educational support helps to improve the quality of life of the patient.

Barakat, et al.(2007) studied the role of coping strategies, specifically negative thinking, in mediating the association of pain with symptoms of anxiety and depression in adolescents with sickle cell anaemia. The analyzed data indicate that lower family income was associated with higher report of pain and negative thinking. Barakat found that age, gender, and grade of adolescence were not significantly correlated with pain, negative thinking, depression and anxiety variables but income was significantly and inversely correlated with interference with school activity, and negative thinking. Wachholtz, et. al, (2007) examined the relationship between spirituality, coping, and pain and found that there is growing recognition that persistent pain is a complex and multidimensional experience stemming from the interrelationship among biological, psychological, social, and spiritual factors. Spiritual and religious coping may affect a number of different physiological, psychological, neurological, and emotional domains that influence pain perception and tolerance.

Balgir (2010) studied intervention and prevention of hereditary haemolytic disorders through KAP (Knowledge, Attitude, and Practice) approach in Bhuiyan and Kharia tribe of Sundergarh district of Orissa, during 2000-2004. He studied pre- and post-intervention KAP through IEC (Information, Education, and Communication) material and found that after IEC, their knowledge was considerably improved. He suggested that sensitization, motivation and proper education with sincerity and community participation are the key sources of successful and effective intervention. 


\section{Psychological and Biological Perspective of Sickle Cell Anemia: A Systematic Review of Literature}

Anie \& Green ( 2012) reviewed psychological interventions for individual with sickle cell disease which might complement current medical treatment and felt that their efficacy has yielded encouraging results. Evidence for the efficacy of psychological therapies in Sickle cell disease is currently limited. Their review has identified the need for well designed; multicenter randomized controlled trial assessing the effectiveness of specific interventions in sickle cell disease. The authors searched for randomized or quasi-randomized controlled trial which compared psychological treatments to each other or to no treatment in sickle cell disease. The author believes that some patient education seemed relevant for children and adolescents, while methods to improve the ability to cope with sickle cell are important for both children and adults.

\section{DISCUSSION AND CONCLUSION}

The present review aims that the biological, and psychological factors are related to the risk factors for the origin of sickle cell anemia. The review work searches in total 65 studies in different databases, some studies have related to the sickle cell anemia etiology and other health related complication for the sickles cell disease persons, 22 studies were dealing with etiology, origin of sickle cell anemia. Few studies have evidence for the biological, anthropological and psychological factors are related to the origin of sickle cell anemia and other studies have evidence of the other complication and problems of the sickle cell disease suffering people.

\section{Acknowledgments}

The author appreciates all those who participated in the study and helped to facilitate the research process.

\section{Conflict of Interests}

The author declared no conflict of interests.

\section{REFERENCES}

Anie, K. A. (2005). Psychological complications in sickle cell disease. British journal of haematology, 129(6), 723-729.

Anie, K. A.\& Green, J. ( 2012). Psychological therapies for sickle cell disease and pain. Cochrane Database Syst. Rev., 2.

Balgir, R. S. ( 2005). The spectrum of haemoglobin variants in two scheduled tribes of Sundargarh district in north-western Orissa, India. Annals of human biology, 32(5), 560573.

Balgir, R. S. (2007).Identification of a rare blood group, "Bombay (Oh) phenotype," in Bhuyan tribe of Northwestern Orissa, India. Indian J. Hum. Genet., 13, 109-13.

Balgir, R. S. (2010). Genetic diversity of haemoglobinopathies, G6PD deficiency and ABO and Rhesus blob group in two isolates of a primitive Kharia Tribe in Sundergarh district of North western Orissa, India. J. Community Jene, 1: 117-123. 


\section{Psychological and Biological Perspective of Sickle Cell Anemia: A Systematic Review of Literature}

Balgir, R. S. (2010). Intervention and Prevention of hereditary hemolytic disorder in two ethnic community of Sundergarh district of North western Orissa: A experience from KAP studies. Online J. Health Allied SCS, 9 (3):4.

Barakat, L. P., Patterson, C. A., Weinberger, B. S., Simon, K., Gonzalez, E. R., \& Dampier, C. (2007). A prospective study of the role of coping and family functioning in health outcomes for adolescents with sickle cell disease. Journal of Pediatric Hematology/Oncology, 29(11), 752-760.

Bhatia, H. M. \& Rao, V. R. (1987). Genetics atlas of the Indian Tribe. Published by Inst. Of Immunohaematology, (ICMR) Bombay, India.

Dampier, C., Ely, B., \& Brodecki, D. ( 2002). Characteristics of pain managed at home in children and adolescents with sickle cell disease by using diary self-reports. The Journal of Pain, 3(6), 461-470.

Deshmukh, P. et al (2006). Prevalence of sickle cell disorders in rural Wardha. IJCM, 31(1).

Doshi, N., Chaodhari, S., Shah, N., Joshi, T., Shah, M. \& Singh, U. (2011). Prevalence of sickle cell disease in rural Pipalwada, Gujrat. National Journal of Community Med, 2 (2): 284-288.

Dunlop, K. J., \& Mozumdeu, U. (1952). The occurrence of sickle cell anaemia among a group of tea garden labourers in Upper Assam. Indian medical gazette, 87(9), 387-91.

Gupta, R. B. (2006). Sickle cell disease load in Madhya Pradesh. RMRCT UPDATE, Jabalpur, 3 (1): April 2006.

Harris, A., Parker, N., \& Barker, C. (1998). Adults with sickle cell disease: Psychological impact and experience of hospital services. Psychology, health \& medicine, 3(2), 171-179.

Hasan, S. P., Hashmi, S., Alhassen, M., Lawson, W., \& Castro, O. (2003). Depression in sickle cell disease. Journal of the National Medical Association, 95(7), 533.

Hurtig, A. L.\& White, L. S. (1986). Psychological adjustment in children and adolescents withsickle cell disease. Journal of Pediatric Psychology, 11: 411-427.

IANS (2010). Sickle cell patient's number rising globally: expert (Lead).November 22, 9:01:51. MA.

ICMR Report (1986). Tribal studies in Jhabua, Ratlam, Ambikapur, Raipur Dist. of Madhya Pradesh.

Ingram, V. M. ( 2004). Sickle-cell anemia hemoglobin: the molecular biology of the first “molecular disease”- the crucial importance of serendipity. Genetics, 167(1), 1-7.

Jain, R. C.(1989). "Restriction endonuclease analysis of DNA in sickle cell lesions among tribals of Bihar, Madhya Pradesh, Gujarat \& Rajasthan." The Indian journal of medical research, 90,346-350.

Kate S. L. \& D. P. Lingojwar, (2002). Epidemiology of Sickle Cell Disorder in the State of Maharashtra. Int. J. Hum Genet, 2(3): 161-167.

Lehmann, H. \& Cutbush, M. (1952). Sickle cell trait in southern India. Brit. Med. Jour, 1: 404405. 


\section{Psychological and Biological Perspective of Sickle Cell Anemia: A Systematic Review of Literature}

Ohaeri, J.U., Shokunbi, W.A., Akinlade, K.S., \& Dare, L.O. (1995). The psychosocial Problems of Sickle Cell Disease Sufferers and Their Methods of Coping. Social Science \& Medicine. 40(7), 955-960.

Pandey, U. P. (1972). Haemoglobinopathies in adults at Raipur. Ph.D. Thesis, Pt. Ravishankar Shukla University Raipur (Unpublished).

Patra, P. K., Khodiar,P. K., Chauhan, S., Dalla, A. R. \& Serjeant (2011). Screening for the sicklecell gene in C.G. states, India: An approach to a major public health problem. $J$. Community Genet, 2: 147-151.

Pauling, L., Itano, H. A., Singer, S. J. \& Wells,I. C. (1949). Sickle cell anaemia, a molecular disease. Science, 110:543-548.

Platt, O. S., Thorington, B. D., Brambilla, D. J., Milner, P. F., Rosse, W. F., Vichinsky, E., \& Kinney, T. R. (1991). Pain in sickle cell disease: rates and risk factors. New England Journal of Medicine, 325(1), 11-16.

Singh, M. P. S. S., Gupta, R. B., \&Kumar, S. (2008). Status of sickle hemoglobin and anemia among gond populations of panna district, Madhyapradesh.Tribal Health Bulletin, 14(1,2), 13-18.

Steinberg, M. H., Forget, B. G., Higgs, D. R., \& Nagel, R. L. (2001). Disorders of hemoglobin. Disorders of hemoglobin.

Wachholtz, A. B., Pearce, M. J., \& Koenig, H. (2007). Exploring the relationship between spirituality, coping, and pain. Journal of behavioral medicine, 30(4), 311-318.

Whitten, C. F., \& Fischhoff, J. (1974). Psychosocial effects of sickle cell disease. Archives of Internal Medicine, 133(4), 681-689.

World Health Organization. (2006). Sickle-cell anaemia- report by the secretariat 1-5. Geneva: Fifty-Ninth World Health Assembly, A59/9.

How to cite this article: Janghel G, Ajagalley R, Bhagat V (2017), Psychological and Biological Perspective of Sickle Cell Anemia: A Systematic Review of Literature, International Journal of Indian Psychology, Volume 4, Issue 2, No. 86, ISSN:2348-5396 (e), ISSN:2349-3429 (p), DIP:18.01.033/20170402, ISBN:978-1-365-68609-2 